VERES Zoltán - SAJTOS László

\title{
ÉSZLELT KOCKÁZAT, ÉRTÉK ÉS PROJEKTKOMPETENCIÁK
}

A marketing alapkategóriái között a vásárlást megelózó észlelt kockázat és a termék által kínált érték problematikáját számos kutató vizsgálta. A fogyasztói piac/fizikai termék kontextusban különösképpen úgy túnhet, hogy a kutatás fehér foltjai már eltúntek. Nem ilyen tiszta azonban a kép, ha a vizsgálatokat kiterjesztjük a szolgáltatáspiacra, amelynek tudományos feltárása hagyományosan elmarad a fizikai termékekétól. A szerzók kutatásának fókuszában a szolgáltató tevékenységek egy speciális szegmense, a projektjellegú szolgáltatások állnak. Ez a terület az észlelt kockázat és az észlelt érték kutatása szempontjából a szolgáltatáspiacon belül is ,halmozottan hátrányos helyzetúnek” tekinthetố. Egyrészt azért, mert ez nem kizárólag, de dominánsan - szervezeti piaci problematika, és ennek kutathatósága természeténél fogva korlátozott, másrészt a projektmarketing - amely az alkalmazott marketingterületek között is viszonylag késốn, a 90-es évek elején önállósodott - csak egy szúk kutatói hálózat érdekterülete. Természetesen az IMP védóernyốje alatt ez a terület is gyorsan fejlódik, jóllehet a kutatható témák számossága még tekintélyes.

Kulcsszavak: kockázat, érték, projektjellegú szolgáltatások

Tanulmányunk két alapkategóriájának, az észlelt kockázatnak és az észlelt értéknek a szakirodalomban számos elôzménye ismert (Ruofan, 2009).

\section{Az észlelt kockázat és az észlelt érték modellezhetôsége}

\section{Az észlelt kockázat}

A kockázat valamely negatív hatású, jövőbeni valószínúségi esemény. Az észlelt kockázat fogalma a marketingben a 60-as évtized elején honosodott meg, és leggyakrabban egy a vevốt a vásárlásban korlátozó inhibitorként értelmezik (Dhalakia, 2001). Miközben számos definíció nem tesz különbséget észlelt kockázat (perceived risk) és bizonytalanság (uncertainty) között (mint pl. Taylor, 1974), az újabb felfogások (mint pl. Dowling - Staelin, 1994) arra az álláspontra helyezkednek, hogy a bizonytalanság és a kimenetel megkülönböztetése az észlelt kockázat idóbeliségére utal.

A kockázat vevőoldali mérlegelését úgy képzeljük el, mint a különbözố alternatívák összehasonlítását (Aqueveque, 2006). Késốbb látni fogjuk, hogy az általunk vizsgált tranzakciótípus esetében a jelenség ettól több szempontból is eltér. Az észlelt kockázat lehetséges dimenzióit Jacoby és Kaplan (1972) határozzák meg máig elfogadott struktúrában, és a szolgáltatástranzakciókat Garner (1986) bővíti ki az időfaktorral. Modelljükből, továbbá abból a megfontolásból kiindulva, hogy a projekt mindig egy eredmény elérését túzi ki célul, mi a szállító várható teljesítményéhez köthetố eredménykockázatot (performance risk) állítjuk vizsgálódásaink középpontjába.

Ami az észlelt kockázat determinánsait illeti, a következóket lehet számba venni:

a) az áru fizikai kontra szolgáltatásjellege. Utóbbi többnyire szignifikáns kockázatérzet-növekedést eredményez (Guseman, 1981; Murray - Schlacter, 1990). Ez azzal függ össze, hogy számos szolgáltatás esetében nehezebb felmérni a vásárlás kimenetelét (értsd: eredménykockázatát).

b) az ár. Ennek szerepe ambivalens. A magas ár növeli a potenciális pénzügyi veszteséget, egyúttal a magas minőséget is üzenheti.

c) cégimázs és hírnév. Negatív korreláció mutatható ki az észlelt kockázattal (lásd erról például Havlena és DeSarbo [1991] kutatásait).

d) személyiség szerepe. A döntéshozó(k) kockázatviselési attitúdje különböző lehet, és ez a szervezeti piacon sem elhanyagolható szempont. 
e) az eladó-vevő kapcsolat története. Ennek hatásáról számos empirikus bizonyíték gyúlt össze (Ganesan, 1994; Sheth - Parvatiyar, 1995).

f) az idôtényezô. Ez tipikusan szolgáltatáspiaci jelenség, és az ún. real-time áruk folyamatjellegéból származtatható. Ahogy ugyanis a szolgáltatásminóség is az idő függvénye (lásd az ingadozás vagy más néven heterogenitás elvét a szolgáltatásmarketingben: Veres, 2009c: 46-47. o.), az észlelt kockázat is hasonlóképpen ingadozik.

g) az eladó és vevô közötti interakciók. Ezt leggyakrabban úgy interpretálják, hogy minél több az interakcióban a kiszámíthatóság (pl. rutinvásárlás esetén), annál kevésbé járul hozzá az interakció a kockázatérzethez, és fordítva.

A fentiek érvényességét a projektek észlelt eredménykockázatára késôbb fogjuk látni.

\section{Az észlelt érték}

Az észlelt érték esetén többnyire a vásárlást megelőzô észlelésre gondolunk, de ez is végighúzódik a teljes tranzakciós folyamaton. Az egyszerúbb „megéri az árát" megközelítés mellett (mint pl. Newman, 1988) erősödik a teljes körú előnyáldozat trade-off felfogás (pl. Zeithaml, 1988; Lovelock, 2001), mint a teljes hasznosság értékelése. Miként az észlelt kockázat kutatásában, úgy itt is a fogyasztói piac dominál, de vannak szervezeti piaci eredmények is (pl. Lapierre, 2000). Az észlelt érték dimenzióiként jellemzően a kognitív és az affektív dimenziót értelmezik (pl. Anderson - Narus, 1990; Sweeney - Soutar, 2001). Funkcionális értelemben az eredményérték (goal performance value) és a pénzügyi érték (financial performance value) különböztethető meg. Szolgáltatás-tranzakciók esetén ehhez adódik hozzá a folyamatérték (process performance value).

Az észlelt érték determinánsai hasonlóképpen csoportosíthatóak, mint ahogy azt az észlelt kockázat esetén tettuik. Nem megoldott azonban az észlelt kockázat és érték kapcsolatának feltárása. Az összefüggés modellezésére egy lehetséges megoldás az, hogy a kockázatérzetnek az észlelt értékre gyakorolt hatását hipotetizáljuk. Ezzel azt feltételezzük, hogy a kockázatérzet mint inhibitor csökkentheti a teljes észlelt értéket. Minket azonban témánk szempontjából jobban érdekel az, hogy

- milyen az észlelt érték kockázatérzetet csökkentő hatása?,

továbbá,

- hogyan lehet kockázatkommunikációval (risk communication) semlegesíteni a kockázatérzet értékre gyakorolt kedvezôtlen hatását?

\section{Kockázatérzet és észlelt érték a projektpiacon}

Ahogy a bevezetóben jeleztuik, vizsgálódásaink a projektjellegú tevékenységekre fókuszálnak. A projekttípusú üzleti tevékenység tárgya a klasszikus felfogás szerint: a nagyberendezés-szállítás ${ }^{1}$. Ekkor az árucsere tárgya egy bonyolult fizikai objektum (hardver, létesítmény), amihez kiegészítő szolgáltatások (szoftver) tömege kapcsolódhat: mérnöki-konzultációs, pénzügyi-kereskedelmi és különféle szellemi termékek (pl. termelési eljárások) átadása. Ez az ügylettípus a hardver típusú beruházási projekt, ahol a nagyberendezés megvalósítása projektformában történik.

Jóllehet a projektügyletek fizikai terméktartalma tekintélyes lehet, ebben az árucsoportban nem olyan egyértelmú, hogy a vevő terméket vásárol szolgáltatásokkal együtt, vagy mindenekelőtt szolgáltatást vásárol, amelynek egy termékszállítás a fizikai háttere. Ez nyilvánvaló, amikor a szállító kizárólag tanácsadó, szervező, koordináló szerepet vállal a beruházásban. A vevô nézôpontjából közömbös, hogy a kivitelezést lebonyolító partner gyártója-e egyes inputoknak vagy sem. Ố egy komplex szolgáltatást vásárol, amelyre azért van szüksége, mert a jó megoldás megítélése túlmegy a felkészültségén (Schmidt - Wagner, 1985,: 422. o.). Kiemelkedő szerepe van a projektkompetencia ígéretének, a komplettségi felárat ugyanis a projektszervezésben való jártasságért fizeti a vevő. ${ }^{2}$ Amennyiben a beruházó rendelkezne projektszervezési ismeretekkel és megfelelő személyzettel, akkor a hardver részegységeiból maga is összeállíthatná az ügylet tárgyát. A projektszállító kompetenciája azonban tartalmazza a rendszerré valóösszeépítés tudását is. Avevőnem terméket, hanem értéket, közelebbrôl tudás/kompeteniaalapú várható elónyöket (knowledge/competence-based expectations of benefits) vásárol (Pa és- Siemplenski, 1983: 92. o.). Vargo és Lusch (2004: 8. o.) téziseivel szólva: „A termék a szolgáltatás elosztására szolgál.” és „A versenyelőny alapforrása a tudás.”

Általánosságban azokat a programokat nevezzük projektnek, amelyekben egy

idóben határolt (kezdettel és befejezéssel jellemezhetô) csoporttevékenység valamely célfeladat megvalósítására irányul.

Ebből a projektdefinícióból kiindulva olyan további üzleti tevékenységeket is ide kell sorolni. ahol az ügylet tárgya egy hardvert nem, vagy alig tartalmazó szolgáltatás (pl. consulting-engineering, tervezés, termelési eljárás átadása, megbízásos kutatás-fejlesztés, ad hoc piackutatás, reklámkampányok menedzselése, tanácsadás, rendezvényszervezés stb.). Fentiek alap- 
ján arra az álláspontra helyezkedünk, hogy a különféle projekteket szolgáltatás-nézópontból vizsgáljuk, és a fizikai tartalmat úgy fogjuk fel, mint a kockázatészlelés moderátorát.

\section{A projekttípusú ügyletek sajátosságai}

A projekt marketing tárgyú források kimerítően tárgyalják a projekttípusú ügyletek marketingsajátosságait, illetve azokat a jellemzóket, amelyek a projektpiaci marketingtevékenységre közvetlen hatást gyakorolnak. $\mathrm{Az}$ alábbiakban a legfontosabb sajátosságokat összegezzük (Cova - Salle, 1999: 19-28. o.; Coa - Ghauri - Salle, 2002: 23-31. o.; Veres - Buzás, 2006):

- A projektüzletágban a legsúlyosabb kockázatelem a szállító komplett eredményfelelóssége, az a kötelezettség, hogy a sikeres teljesítés összes feltételének számbavétele a szállító feladata. Ez a teljesítményigazolás befejezéséig fennálló kockázati tényező.

- A projekt tárgya természeténél fogva egyedi termék. A feladat a szállító számára is új, egyedi jellegú, mert ugyanabban a kapcsolatrendszerben, ugyanolyan korszerúségi fokon ritkán hajt végre ismételten tranzakciót.

- A problémák megoldását nehezíti a projektobjektum rendszerjellege. Az amerikai szaknyelv ezért használja az ilyen ügyletekre a rendszereladás (system selling) terminust. A rendszerjelleg nem csak a hardverre érvényes, hanem például a döntési mechanizmusra is.

- A partnerkapcsolatokban múködő ellentétes érdekekbool adódnak az ún. együttmúködési kockázatok. Ez a feleket arra csábítja, hogy kihasználják a másik fél ismereteinek korlátozottságát. Ugyanakkor például a vevô és a konzultáns kapcsolata is függố partnerkapcsolat, hiszen a konzultáns hosszabb távú piaci kapcsolatai szempontjából érdekelt a szállítóval való jó együttmúködésben (Schmidt - Wagner, 1985).

- Az ügyleti folyamat különbözó fázisokkal jellemezhetô, elhúzódó interakciósorozat a szereplők között. Ilyen fázisok például: megvalósíthatósági vizsgálatok, ajánlati felhívás (briefing folyamat), szállító(k) kiválasztása, projektmegvalósítás, debriefing stb.

- A beruházási javak piacán jól ismert jelenség, a kereslet lökésszerú jellege itt azzal súlyosbodik, hogy a szállító-vevó kapcsolat természeténél fogva idószakos. A projekt megvalósítása során nagyon szoros, a végleges átadást követően viszont véglegesen, vagy legalábbis hosszabb idôre elveszítheti motiváltságát.
A fentieket összegezve a projekttípusú üzleti tevékenység legfontosabb sajátosságainak - a szolgáltatásdimenzió fontossága mellett - négy dolgot tekintünk:

1) a szállító és az igénybe vevô kapcsolata nem folytonos (discontinuit),

2) az ügylet számos elemében egyedi (uniquenes),

3) az ügylet és tárgya egy bonyolult, komplex rendszer (complexit),

4) az ügylet és a kapcsolat lefutása idóben elhúzódó, fázisos jellegú (phase-specific).

Az elsố három tényezốt összefoglaló néven - a kezdốbetúkboól - DUC-modellnek neveztük el, és ez a koncepció azóta elfogadottá vált a szakirodalomban (lásd pl. Cova - Salle, 2007). A DUC-modell alapján három alapvető projketjellemzốt különböztetünk meg: a diszkontinuitást, az egyediséget és a komplexitást. A szállító-vevő kapcsolat előtörténete fontos moderátortényezố a kockázatérzetben, de példának okáért a projekt engineering üzletág menedzselését rendkívüli mértékben megnehezítik a kapcsolatra jellemző folytonossági hiányok (diszkontinuitás), ahol a szakadási időszakok (a kapcsolat inaktív fázisai) sokszor évekig is eltarthatnak (Mandják-Veres, 1998,; Cova -, Ghauri - Salle, 2002). A diszkontinuitás azt jelenti, hogy a szállító és a vevő között nem lehet olyan kapcsolatot felépíteni, amelyet folyamatos tranzakciók táplálnak, és a projekt befejezésekor a felek közötti közvetlen kapcsolat alvó fázisba mehet át (Hadjikhani, 1996). Az egyediség lényege, hogy - a kivételes eseteket leszámítva - egy projekt olyan egyedi paraméterek, szempontok figyelembevételét teszi szükségessé, hogy az még a szállító számára is új feladatnak minôsül. A komplexitás elemei a következôk: rendszerszerú kínálati csomag; összetett beszerzési centrum; az érintettek széles köre; az észlelt kockázat interdependenciái stb.

\section{A projektfolyamat kockázati viszonyai}

Először vegyük a Cova - Ghauri - Salle-féle folyamatmodellt (Cova - Salle, 2007). A modell a projektszállító nézőpontjából a tervezéstôl a szerződéskötésig értelmezi a folyamatot. Eszerint a prioritások rögzítését követi egy olyan projektfüggetlen fázis, amely két síkon értelmezhetô. Egyrészt a szállító funkcionális fejlesztést hajt végre, azaz folyamatosan fejleszti piacképes kompetenciáit, felkészülve a célcsoportok várható problémáinak megoldására. Ez olyan diverzifikációt igényel, amelyben a szállító vezetô projektterméke (core offer) mellett sok egyéb problémamegoldásra is vállalkozik saját kompetenciája alapján vagy partnerszállítók bevonásával (external offer). A funkcionális fejlesztéssel egyidejúleg a szállító kapcsolati hálóját is folyamatosan fejleszti. A kapcsolati hálótérben ott 
vannak azok a felhasználók, akik késóbb szerződéses partnerek lehetnek. A folyamat következó fázisa a pretender fázis, amelyben a szállító már számba veszi a projektpiaci keresletet, azaz a lehetséges vevők körét, és egy szúréses szelekciós eljárással kiválasztja azokat a (pl. versenytárgyalási kiírások formájában megjelenô) vásárlói problémákat, amelyek elnyerésébe célszerú befektetnie. Az ajánlati fázis az ajánlatadás - tárgyalás-szerződés láncot jelenti.

A projektek észlelt eredménykockázata a korábban tárgyalt dimenziókban különböző mértékben és módon jelenik meg. A szolgáltatásjelleg korlátozza az eredmény megfoghatóságát, az ár a minőség üzenetével közvetett hatású. A cégimázs fontossága a projekt értékével arányosan nő, és egyes területeken ismeretlen szállítóként lehetetlen önállóan megbízáshoz jutni. A projektfolyamatban részt vevő szakemberek kockázati attitứdje és a szállító-megbízó kapcsolat moderálja az eredménykockázat észlelését. A projekt egyedisége és eredménykockázata olyan tényező, amely már a pretender fázistól kezdődően egészen a végleges átadásig (sőt, erősebb partnerkapcsolatokban sokszor azon túl is) szükségessé teszi a felek interaktív, problémamegoldó kapcsolatát. Az észlelt eredménykockázat időfüggése azt jelenti, hogy a teljes tranzakciós folyamatot terheli az a bizonytalanság, ami a (vég)eredmény jóságához fúződik, sôt - folyamatorientált szolgáltatások esetében - maga a folyamat jósága is része a vevő által elvárt eredménynek.

A projektsajátosságokból származó problémák megoldásában vannak további megfontolások. Közülük a fontosabbak (Cova - Salle, 196; Engelhardt, 1993; Veres, 2007; Veres, 2009b):

- Az egyediség következtében standard megoldások csak korlátozottan, moduláris formában alkalmazhatók. Az egyedi termékek esetén tipikus elsố vásárlási szituáció itt $a$ szállitó számára is új feladat, mivel az objektum számos részletében nem specifikálható előre. Ezeket a szolgáltatástermékeket az igénybe vevô aktív bevonásával, együtt hozzák létre.

- A hosszú megvalósítási idôtartamból származik a teljesités kétoldalú (bilaterális) eredménykockázata. A szállító a projekt átadásának időszakára eljut a közel 100\%-os teljesítésig, a nemfizetés kockázata tehát számára az idő előrehaladtával egyre nô. A vevő viszont - jóllehet az átadás előtti pillanatra látszólag mindenhez hozzájutott - csak az átvételt követően látja bizonyítottnak, hogy a projekt tárgya valóban teljesíti a szerződésben vállaltakat. ${ }^{3}$ Számára tehát a nemteljesítés kockázata a projekt folyamán alig csökken, esetleg még nőhet is. A hírnév védelme mint stratégiai cél emiatt megköveteli az intenzív kockázatérzet-csökkentő kapcsolatmenedzsmentet. Az észlelt kockázatnak ezt a dinamikáját szemléltetjük a kockázatészlelési tölcsérmodellel az 1. ábrán. A kockázati tölcséren jól látszik:

a) A projektkockázat folyamatjellege (vízszintes dimenzió), azaz hogy a kockázat és a kockázatérzet nem független a projekt történéseitôl, azoktól a tranzakciós epizódoktól, amelyek a megvalósítás folyamatát alkotják. Ez akár még külső hatásokat is jelenthet, pl. valamely új piaci információ megszerzését.

b) A projektkockázat egyre növekvő ingadozási terét (függóleges dimenzió), azaz hogy a várható veszteségek miatt a feleknek egyre kockázatosabb „kiszállni” az ügyletból, következésképpen egyre csökken az alternatív partnerkapcsolatra történó váltás esélye. Ennek legsúlyosabb - bizonyosan veszteséges - kimenetele az, amikor a projekt folyamatában az aktorok túlhaladnak azon a ponton, ahol még van esély a váltás üzletileg gazdaságos menedzselésére (angolul: point of no return).

1. ábra

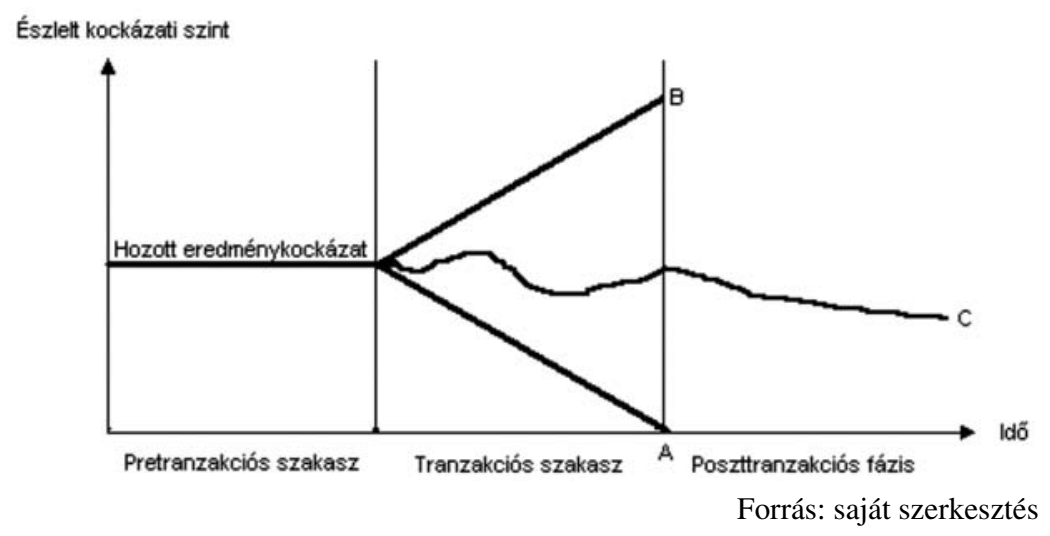

Ahol az

A jelú küszöbgörbe: az az ideális eset, amikor a szolgáltatás folyamán az észlelt eredménykockázat nullára csökken.

B-jelú küszöbgörbe: nem kívánt eredmény: a szolgáltatás során az észlelt eredménykockázat erôteljesen nó.

$C$ jelú görbe: az észlelt eredménykockázat valós értéke az A és B közötti mezóben ingadozó érték lesz, amely a projekttapasztalatok utólagos értékelésével még a poszttranzakciós fázisban is változhat, mielőtt stabilizálódik.

- A szállító bonyolult kapcsolatrendszerének menedzsmentje kétirányú feladat. Szúkebb értelem- 
ben az ügyletek partnerkapcsolati problémakezelését, stratégiai szempontból pedig a hálózatépítést (networking) jelenti. Hangsúlyozni kell, hogy a hálózatépítés a szervezeti piacon mindig személyek közötti interakciókkal valósul meg. Bizonyított például, hogy az aktorok közötti kritikus események lényeges szerepet játszanak a hálózat fejlődésében (Haimala - Salminen, 2006).

\section{Immateriális érték és projektkompetenciák}

A fenntartható versenyelőny megteremtésének alapproblémája a változó környezethez való sikeres és hosszú távú alkalmazkodás a szervezet rendelkezésére álló erôforrások segítségével. A stratégiai célok belső erôforrásai a projektpiacon:

$$
\begin{aligned}
& \text { tárgyi = pénzügyi, hardver, } \\
& \text { immateriális = technológia, hírnév, szövetség, } \\
& \text { jogosultság (pl. akkreditáció), } \\
& \text { humán = készség, know-how. }
\end{aligned}
$$

A kompetencia szótári megfogalmazásban: illetékesség, jogosultság, szakértelem. Ehhez soroljuk még a készségek, képességek tárházát, valamilyen információ birtoklását, illetve a ,jártasságot” egy adott területen belül. A gazdálkodás tárgya az a kompetencia, ami egyszerre jelent hozzáértést egy bizonyos felmerülő feladathoz (technológia, know-how stb.) és illetékességet, hogy az aktor e feladattal foglalkozzék (lásd az eróforrások között a jogosultságot). A tudásból úgy lesz a feladathoz való hozzáértés, hogy a feladattal kapcsolatos információ társul hozzá - ugyanígy állítja elő az illetékességet a feladattal szorosabban vagy lazábban összefüggő okirat ${ }^{4}$ (Garai, 2003: 23. o.).

A kompetenciaalapú észlelt érték lehet a kockázatérzet egyik kulcsdeterminánsa. A kompetenciát úgy értelmezzük, mint az episztemikus kompetencia és a heurisztikus kompetencia összességét a projekt tárgyát képező ,probléma” megoldásában. Eszerint az episztemikus kompetencia mintegy bizonyíték korábbi sikeres teljesítményekre (lásd referenciák), míg a heurisztikus kompetencia - releváns referenciák hiányában - a megbízhatóság ígérete arra, hogy az aktor képes megbirkózni a projekt megoldási nehézségeivel (pl. szakmai szövetségi tagság). Ez a megközelítés árnyaltabb, mint Grant (1995) vagy késóbb Möller (2006) álláspontja, akik a fenti két dimenziót összemossák.

A projektügyletekben az aktorok a megbízói oldalon is többé-kevésbé hozzáértő (kompetens) felek, bizonyos fokig a technológia szakértôi, és a tranzakcióban aktív szerepet vállalnak. Marketingterminussal kifejezve a vevoók bevonódása számottevő lehet. A kompetencia kiterjesztése a megbízó oldalára éppen ezzel az aktivitással magyarázható (Cova - Salle, 1999; Bettencourt et al., 2002; Axelsson - Wynstra, 2002). Mint minden más kategória a szervezeti piacokon, a kompetencia is az egyén szintjétól a csoportszinteken át az összvállalati szintig értelmezhető (Grant, 1995). Szervezeti szinten a kompetencia a vállalat képessége a tudás- és technológiaáram koordinálására (Awuah, 2001; Hamel - Prahalad, 1994). A vállalati kompetencia hierarchikus (Banerjee, 2003) és önfejlesztő (Conceição - Heitor, 2002).

Az üzleti piaci aktorok kompetenciájának megértéséhez sokban hozzájárultak Karl Erik Sveiby kutatásai (1997). Koncepciója szerint a vállalat immateriális értékének legértékesebb elemei: a kompetenciák, a márka és a kapcsolatok. A kompetenciát úgy definiálja, mint az aktorok ,,azon képességét, hogy sokféle szituációban tudnak cselekedni”. Érdemes idézni a projektpiacra vonatkoztatható megállapításait: „Egy építőipari cég legfóbb (immateriális) vagyona a komplex projektek kivitelezésére való képesség... A tanácsadó cégek... fő értéke a személyzet kompetenciájában és az ügyfelekkel kialakított kapcsolatokban keresendő" (Sveiby, 1997: 68. o.). A kompetencia- és a kapcsolatrendszer kölcsönhatására építve a szállítóknak az immateriális értékek maximális hasznosítása érdekében meg kell kísérelni szorosabb kapcsolatot kiépíteni partnereikkel.

A kompetencia az aktorok viszonyában többféleképpen is értelmezhetô. A lehetséges hat kompetenciadimenzió a 2. ábrán követhető a számozás sorrendjében:

1) A szolgáltatást nyújtó „valós” kompetenciája: a „,szakma által közös megegyezésen alapuló” szükséges kompetenciák a szolgáltatás nyújtásához.

2) A szolgáltatást nyújtó ,vélt" kompetenciája a szolgáltatásra vonatkozóan: szubjektív ítélet a saját szolgáltatói kompetenciájáról.

3)A szolgáltatást nyújtó ,ítélete” a szolgáltatást igénybe vevő hozzáértésére vonatkozóan.

4) A szolgáltatást igénybe vevô saját „,kompetenciája": a megvásárolt szolgáltatás technológiájának ismerete.

2. ábra

\section{Kompetenciastruktúra a szállító-megbízó diádban}

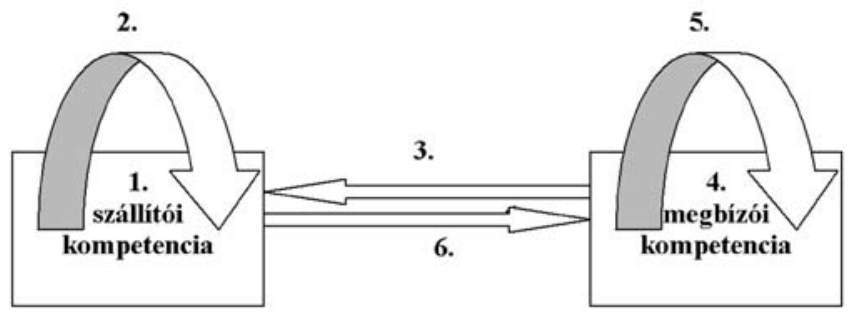

Forrás: Veres, 2007 
5) A szolgáltatást igénybe vevő „vélekedése” a szolgáltatást illető saját hozzáértésérôl.

6) A szolgáltatást igénybe vevő „,vélekedése, ítélete” a szolgáltatást nyújtó kompetenciájáról (szolgáltatás előtti, alatti, utáni). Ez a szúkebben vett marketingdimenzió.

Az egyediség okozza azt az észlelt bizonytalanságot, ami felértékeli a vélt kompetenciák szerepét a kapcsolatban. A szállító által tudatosan fejlesztett kompetenciaimázs a vélt kompetencia alapja. Érdekes lehet annak feltárása, hogy a szolgáltatást igénybe vevô vajon a „szolgáltató kompetens voltát” ítéli-e meg, vagy inkább a szolgáltatásról szóló kommunikációba rejtett kompetenciákat. A szolgáltatás elején valószínú, hogy inkább a kommunikációba rejtett kompetenciák alapján ítéli meg a kockázatokat, míg a szolgáltatás igénybevétele során (illetve után) a kommunikáció kisebb - jóllehet nem elhanyagolható - jelentôséggel bír. Ezt a projektszituációra lefordítva, Golfetto és Gibbert (2006: 906. o.) értelmezését - mely szerint a megbízó piaci bizonytalanságát az ajánlatadók kompetenciaprofiljának megismerése csökkenti - kiterjeszthetjük a tranzakció teljes folyamatára. Így a kompetenciák marketingje (Golfetto - Gibbert, 2006) a pretranzakciós fázisban a piaci bizonytalanságot, a megvalósítási fázisban pedig a tranzakciós bizonytalanságot csökkentheti (lásd a Ford-modellt, Ford 2002).

\section{A kapcsolati dimenzió}

Az elóbbiekben érintettük a kompetencia és a kapcsolat kölcsönhatását. A kapcsolat maga is több síkon jelenhet meg. A komplexitás menedzselhetôsége érdekében a vállalatok közvetett és közvetlen kapcsolatrendszereket múködtetnek (Håkansson - Snehota, 1995), vagy a kapcsolathálóba (network) invesztálnak (Cova - Hoskins, 1997). A hálózatban az egyes kapcsolatok értéke a kapcsolati teljesítményben nyilvánul meg, sốt a network is forrása egy értéknövelő tanulási folyamatnak (Menon Homburg - Beutin, 2005; Eng, 2005). Ennek a kutatási iránynak a képviselôii a hazai business-to-business kutatásokban Mandják Tibor és Simon Judit, akik az üzleti kapcsolatok vizsgálatára fejlesztették ki az üzleti kapcsolatok értékének integrált modelljét (Mandják - Simon, 2007).

A projektpiaci aktorok gyakorlatában a tranzakciós és a kapcsolati orientáció sosem különül el egymástól. Hogy melyik dominál, az partner-, ügylet-, sốt ügyleti fázisfüggoó. A szállító eseti beszállító (out-supplier) pozíciója például a tranzakciós, a tartós partner (insupplier) pozíció pedig inkább a kapcsolati versenymagatartást teszi indokolttá (Cova, 1990; Mandják et al., 1995). Ezt a pluralitást erôsítette meg egy a projektpiacon végzett interjúsorozatunk (Veres, 2007), amely a piaci szereplő́k attitúdjében a tranzakciós és a kapcsolati orientáció keverékét tárta fel.

Együttmúködési kockázatok származhatnak valamely harmadik fél részvételéból is. A konzultánsok igénybevétele (a saját kompetencia „meghosszabbítása”) például csökkenti a vevônek a szállítóval szembeni kockázatait, ugyanakkor a vevő és a konzultáns kapcsolata is függó partnerkapcsolat (Branscomb Auerswald, 2001: 120-122. o.).

Végül megjegyezzük, hogy az egyediség és a nagy érték következtében rendkívül fontos kapcsolati „munka" a kockázatkommunikáció (risk communication). A vevố kockázatérzete ugyanis nagyrészt a megfogható információk hiányából származik. Maga a referenciabázis bemutatása is egyfajta kockázatkommunikáció. A kockázatkommunikációnak egyes szakterületeken (pl. egészségügy) már komoly szakirodalma van, a projektpiacon azonban ilyen irányú kutatások - ismereteink szerint - még nem folytak. Megítélésünk szerint a kockázati tölcsérrel modellezett kockázati tér-idő kontinuum menedzselésének egyik kulcstényezője a hatékony kockázatkommunikáció. Amennyiben a kockázatkommunikációt úgy tekintjük, mint az üzleti szereplók olyan aktivitását, amely a partnervállalati elégedettséget is képes fejleszteni, akkor ez is egyfajta marketingkompetenciaként értelmezhető (lásd erról Golfettos - Gibbert, 2006).

\section{Parányi kitekintés az SDL-modellre}

Érdemes röviden kitérni a fenti projektproblematika értelmezhetőségére a Vargo és Lusch-féle Service Dominant Logic modelljében (Vargos - Lusch, 2004). Ahogy azt egy korábbi tanulmányunkban (Veres, 2009a) már részletesen elemeztük, az SDL-modell egyes téziseiból kiindulva a következók körvonalazódnak:

Tézis: Az üzleti tranzakciókban a csere alapegysége a felhasznált kompetencia.

Ez az értékteremtó problémamegoldás a projektügyletek lényege, és láttuk, hogy ezt a projektkutatók már a 80as években megfogalmazták. Stratégiai következménye az, hogy a versenyelóny fenntarthatósága az immateriális és a humán erőforrások fejlesztésében rejlik.

Tézis: A versenyelőnyt a kompetenciák biztosítják.

A kompetenciák termékhez, technológiához vagy menedzsmenthez köthetốk, és a versenykényszer hatására fejlődnek. Ilyen értelemben a kompetencia a szervezet tanulóképességét (dinamikus kompetencia) is jelenti. A projektpiaci versenyelőnyt legfő́képpen három területen stabilizálhatja a kompetencia: a projektfejlesztésben, a kapcsolatiháló- (network) menedzsmentben és az ügyfélkapcsolat-menedzsmentben. 
Tézis: Az eladó „csak” értékajánlatot tesz, az értékteremtés a fogyasztó tevékenysége.

A vevőérték egy interaktív értékteremtő folyamat eredménye. Az aktív ügyfél menedzsmentje „csak” segíti ezt az értékteremtó folyamatot. A stratégiai menedzsment szintjén ez azt jelenti, hogy a környezetelemzés egyik kulcstényezóje a potenciális vevôk értékpreferenciáinak feltárása.

Tézis: A szolgáltatásközpontúság felhasználó- és kapcsolatorientált.

Az ügyfélreszabott legjobb megoldás megértése a feladat. A tailor-made megoldásokra való képesség a legbiztosabb projektpiaci versenyelóny. A kapcsolatorientációból következően a tranzakciót megelőző és az azt követő (pre- és poszttranzakciós) fázisok stratégiai jelentősége sokszor nagyobb, mint magáé a tranzakcióé.

A kompetenciaalapú értékteremtés egyik legjobb rendszerezését Möller (2006) végezte el. Arra a következtetésre jutott, hogy az értékajánlatot három dimenzióban lehet kommunikálni. Az egyik a szakmai (nála: exchange), a másik a kapcsolati (nála: relational), míg a harmadik az ügyleti (nála: proprietary). Mindhárom dimenziót érintettük az előzóekben. A szakmai alatt mi a technológiai problémamegoldó kompetenciát értjük. Ez a kompetencia leszúkítố felfogása, míg a kapcsolati ezt terjeszti ki a hatékony kapcsolatmenedzsmentre. Ez utóbbi a kapcsolati eróforrások (kapcsolati portfólió) optimalizációjának kompetenciája (röviden: kapcsolati kompetencia) (Theoharakis - Sajtos - Hooley, 2009). Az ügyleti kompetencia pedig a tranzakciós orientáció leképeződése az értékmenedzsmentben.

\section{Egy feltáró kutatás tanulságai}

Az elméleti háttér feldolgozását követôen empirikus vizsgálatainkat az 1. táblázat szerinti magyarországi projektpiacokon 2009-ben végzett szakértói in-site mini-fókuszcsoportokkal folytattuk. ${ }^{5}$ Kutatásunk célja a kompetenciaalapú eredménykockázat projektpiaci észlelése és kezelése volt, amiből a következő kutatási kérdéseket származtattuk:

- Milyen mértékig tudatosul a partnerekben a projektek egyedisége?

- Milyen fontosságú a projektszállítók kompetenciájában a problémamegoldó képesség?

- Mennyire érzékelik a projektaktorok a tranzakció kényszerpályajellegét?

- Milyen összefüggést észlelnek a partnervállalat vélt kompetenciája és az eredménykockázat között?

- Mi a kockázat kommunikációjának hatása?
A kutatás célterületei

\begin{tabular}{|l|c|}
\hline \multicolumn{1}{|c|}{ Projekttevékenység } & $\begin{array}{c}\text { Fókusz- } \\
\text { csop. száma }\end{array}$ \\
\hline Ad hoc piackutatás & 20 \\
\hline Építóipari projektek tervezése és kivitelezése & 12 \\
\hline IT-rendszerek telepítése és fejlesztése & 20 \\
\hline Marketingkommunikációs projektek (kampánytervezés stb.) & 20 \\
\hline Médiaügynökség egyedi megbízásai & 12 \\
\hline Pénzpiac (pl. hitelezési; biztosítási projektek) & 16 \\
\hline Tanácsadás (vezetési, szervezetfejlesztési stb) & 16 \\
\hline Üzleti célú eseti rendezvényszervezés & 32 \\
\hline Üzleti turizmus (egyedi incentive programok) & 8 \\
\hline Üzleti képzési projektek (cégspecifikus továbbképzés) & 4 \\
\hline Vegyes egyedi ipari szolgáltatások & 8 \\
\hline Egyedi web-es fejlesztések & 12 \\
\hline Összesen: & $\mathbf{1 8 0}$ \\
\hline
\end{tabular}

- Mi az aktorok kapcsolatának szerepe a kockázatérzetben?

A fókuszcsoportok szervezésénél azt a szempontot követtük, hogy egyenlő arányban legyenek szállítói és megbízói csoportok, a lefolytatott 180 csoportvita tehát 90-90 szállítói, illetve megbízói csoportot jelentett. Egy-egy mini fókuszcsoportba 2-3 döntéshozót toboroztunk. A vizsgálat tárgyát képezô jelenségkomplexum feltárását az alábbi fókuszcsoport-forgatókönyv alapján végeztük. A módszer alkalmazásakor azt a megoldást választottuk, hogy a vita résztvevôit egy hatlépéses állítássorozattal vezetjük végig a kompetenciaalapú kockázatérzet tartalmának feltárásában. A résztvevốknek ezeket az állításokat kellett megvitatni és saját projekttapasztalataik alapján állást foglalniuk. A mini fókuszcsoportos vitákat projektszakértők, ipari marketingesek, továbbá üzleti tudományterületen végzô levelező mesterszakos hallgatók moderálták. A viták helyszínéül - elkerülendő a fókuszlabor sterilitásából adódó kedvezőtlen hatásokat - legtöbb esetben a válaszadók munkahelyét választottuk (in-site FGD).

\section{Szakértối minifókusz-vezérfonal}

1. állitás: A projekt bizonyos fokig mindig egyedi.

2. állitás: A megbízók számára a „termék” fő előnye a szállító képessége a problémamegoldásra.

3. állitás: A projektfolyamat kényszerpálya mindkét fél számára, mert a teljesítés sikere csak a folyamat lezárása után ítélhetố meg. Ez az eredménykockázat forrása.

4. állitás: A kockázatérzetet a partnervállalat vélt kompetenciája enyhíti. Ez a kompetencia általában aszimmetrikus. 
5. állitás: A kockázat kommunikációja a megbízó bizonytalanságát csökkentheti, de a csökkenő bizonytalanság a kockázatérzetet erôsítheti is.

6. állitás: A szállító-vevő kapcsolat a bizalom erősítésével csökkenti a kockázatérzetet.

\section{Eredmények}

A mini fókuszcsoportok átiratainak tartalomelemzéséból - a minifókusz-vezérfonalat követve - az alábbiakat szúrhetjük le.

\section{1. állítás: A projekt bizonyos fokig mindig egyedi.}

A megkérdezettek bizonyos finomításokkal egyetértettek az állítással. A technológia és a környezet gyors változásai következtében különösen a nagy projektek esetében nagyfokú az egyediség, de ennek kockázatai ellen védekezni kell: az ad hoc feladatot rutinszerú lépésekre kell bontani, egyedi tervezésú, de moduláris rendszert kell szállítani. Sok üzletág magasan standardizált ajánlatokat dolgoz ki, az ügyfél problémája azonban mindig egyedi. ,...nem sematikus válaszokat, megközelítéseket akarnak az ügyfelek... Azt várják, hogy mi mindenre megoldást tudunk adni."

Ez kifinomult szolgáltatásadaptációt követel. A marketingszolgáltatók piacán sokszor a megbízó és az időkényszer kényszeríti ki a rutinmegoldásokat, holott az egyedi jobb lenne. Az egyediség mindenesetre megnehezíti az értékesítést...

„Amikor projektértékesítésról beszélünk, akkor nem konkrét dolgot adunk el, a jövóben létrejövó valaminek az értékesitése folyik, és azt a dolgot kell az ügyfélnél bizonyítani, hogy mi ennek a bizonyos dolognak a megvalósitására képesek vagyunk, és ó ezáltal hatékonyabb lesz, és pénzt takarít meg."

...bár egyre inkább okosodik az ügyféloldal. Egy projektnek van egy szakmai dimenziója, meg van egy módszertani dimenziója. A módszertani dimenziója az folyamatosan ugyanaz, a felmérés, igények összesítése, tervezés, tesztelés, ezek a feladatok mindig ismétlődnek.

„Amikor az ügyfélnek ugye van valamilyen igénye... a legjobb helyzet az, amikor együtt találjuk ki, és egy kicsit ennél rosszabb...akinek kalapács van a kezében, az mindent szegnek néz, azaz aki a problémafelvetés pillanatában ott van, a saját nézópontja szerint próbálja a problémát kezelni."

A válaszadók az egyediséget leginkább a rendszerjelleggel kötik össze. A projekt rendszerjellege azért okoz a szállítónak nehézséget, mert vannak új termékek, és ilyenkor a szállítónak is van tudáshiánya, azaz ez egy tanulási folyamat a szállító számára is.

2. állitás: A megbízók számára a „termék" fó elónye a szállító képessége a problémamegoldásra.
Általában igaz, bár az ügyfeleknél felkészült emberek is vannak, sok esetben a saját üzletük folyamatainak a megoldására, de egy dolgot nem tudnak: felelősséget vállalni, hiszen nem tudnak ráhatni a saját szervezetüknek a szereplőire. Ebben nagyon különböznek az állami és a for-profit vevớk: „Gyenge az alkupozíciója annak, aki büdzséból él."

High-tech területeken (pl. telecom) egyre fontosabb a problémák proaktív megközelítése, sốt gyors reagálásként a konkurencia innovatív megoldásait is tudni kell szállítani. Ma már a költséghatékonyság is problémamegoldásnak számít. A klasszikus projektpiacon (pl. építốipar) a hatékony reklamációkezelés a kulcstényezô.

Ebben a kérdéskörben markánsan kiütközött a cégvezetés egymástól eltérő attitúdje. Van, ahol a szoros személyes kapcsolatok talaján a közös problémamegoldás a jellemző, míg máshol a megbízó bevonása nem cél: „,Az ügynökség azért van, hogy a megbizó elkényelmesedhessen."

3. állitás: A projektfolyamat kényszerpálya mindkét fél számára, mert a teljesités sikere csak a folyamat lezárása után itélhetó meg. Ez az eredménykockázat forrása.

Meg kell jegyezni, hogy ezt számos válaszadó nem tudta értelmezni. A kutatási célcsoport nagy része számára azonban ez világos. Ha egy projekt megszakad, akkor a végterméke kvázi megsemmisül. Ez a szolgáltatásoknál mindig így van, mivel „real time” termék.

„...mi ezt próbáljuk sulykolni. Tehát mindenféle mérföldköveknél egyre jobban megkötjük egymás kezét, hogy mi az, aminek meg kell valósulnia...Ha egy nagyon-nagyon hosszú projektról beszélünk, akkor van egy helyzetfelmérés, van egy igényfelmérés, van egy koncepcionális tervezés, akkor a koncepció, és mindegyiket el kell fogadnia az ügyfélnek is, meg a szállítónak is, hogy akkor ez egy közös tudás, ami alapján lépünk tovább."

Sok vállalatnál tehát a kockázat csökkentése teljesen tudatos, és a megoldás is standardnak túnik: folyamatos monitoring vagy folyamatközi ellenőrzési pontok, menet közben milestone-ok beépítése (státusmeetingek), ún. agilis projekt menedzsment $=$ folyamatos beüzemelés + iterációk, munkaterv napi bontásban. Ettól függetlenül lehetetlen elôre tökéletes specifikációt adni a briefingben, mert a használat maga egy tanulási folyamat, következésképpen az ideiglenes átadást követôen a finomhangolás minimum egy év. És tanulni kell a párhuzamos projektekból!

4. állitás: A kockázatérzetet a vélt kompetencia enyhíti. Ez a kompetencia általában aszimmetrikus.

Előfordul, hogy a kompetencia imidzse mögött nincs tartalom. Ezért a megbízó, hogy kockázatát csökkentse, keresi a kompetencia kiterjesztését: ,jogosítványokat” (pl. ISO-minôsítést, képzésben akkreditációt stb.) vár 
a kompetencia igazolására, sokszor harmadik (semleges) felet bíz meg a projekt vezetésével. A megbízóoldali kompetencia segíti a megértést, de amennyiben ez hiányzik, a kommunikációt segítő harmadik félre van szükség. A kompetenciaaszimmetria ismert jelenség, ami egyes üzletágakban rendkívül magas (pl. pénzintézeti szektor), máshol természeténél fogva áll fenn (pl. képzés). Az aszimmetrikus kompetencia a legnagyobb nehézséget a pretranzakciós fázisban jelenti (szükségleti bizonytalanság!), míg az aszimmetria a projekt folyamatában csökkenhet. Érdekes kereszthatás, hogy a business (incentive) turizmusban a megbízó - fogyasztói tapasztalataiból kiindulva - többnyire túlértékeli a kompetenciáját. Általában is jellemző érdekes vélekedés, hogy mindkét fél a másik oldal kockázatát érzi nagyobbnak.

Sajátos a helyzet a tanácsadásban. Itt az ügyfél szakmai kompetenciája bizonyos szempontból nagyobb lehet, mint a tanácsadóé, míg a rendszerszintú, illetve a tapasztalati kompetenciája a tanácsadónak jóval nagyobb. A folyamatban ezek közelednek egymáshoz, tehát az ügyfél megismeri a rendszert, a tanácsadó pedig megismeri az adott vállalatnál szokásos eljárásokat. Ez a tudásközelítés egy menedzselt folyamat.

A rendszerjelleggel összefüggó sajátos kompetenciaaszimmetria az, ami abból származik, hogy az adott projekt eredménye a megbízó nagy rendszeréhez illeszkedik, amit a szállító nem ismer kellő mélységben.

5. állitás: A kockázat kommunikációja a megbízó bizonytalanságát csökkentheti, de a csökkenó bizonytalanság a kockázatérzetet erósítheti is.

A megkérdezettek világosan látják, hogy a megbízónak nagyobb a kockázata, mint a kifizetett pénz, mert akár az egész üzlete ,,bedólhet”. „...egyre inkább marketingszagúnak tünik, hogy minden projekt elején szoktunk közölni a vevóvel bizonyos kockázati tényezóket, már csak önvédelemból is."

A kockázatkommunikáció ebből a marketingnézőpontból a szállítót segíti. A vevő kockázatérzékenysége változik az eladási ciklus során. Ahogy egyre jobban bevonódik a projektbe, megnô a kockázati érzékenysége.

A szükségleti bizonytalanság feltárása nagyon fontos, mert volt rá példa, hogy mire egy hosszú projekt befejeződött, már nem volt szükség a projekt céljára. Az irreális célokról pedig le kell beszélni a megbízót! A kommunikáció rendszeressége egyébként önmagában is kockázatérzet-csökkentő.

A megkérdezettek egy része elismeri, hogy a kockázatkommunikáció növelheti a bizonytalanságot, ezért mindig a megoldással együtt kell kommunikálni.

6. állitás: A szállító-vevó kapcsolat a bizalom erôsítésével csökkenti a kockázatérzetet.
Az állítást kezdetben közhelyesnek vélték, végül a vitákban az a konszenzus alakult ki, hogy jóllehet az állítás igaz, a hosszú kapcsolat elkényelmesít, sôt a vevő nem egyértelmúen érdekelt a hosszú távú kapcsolatban. Több üzletágban tervezett partnerváltások történnek.

Ahol a megtartás a cél, ott azt szisztematizálni kell, és be kell fektetni a kapcsolatba (pl. ügyfélmegtartó rendszeres kisebb fejlesztésekkel a bizalmi kötődés építésére). Ahhoz, hogy a szállító fenn tudja tartani az üzleti múködését, fontos, hogy ott legyen az ügyfélnél. Az ún. support szerződések intézményesítik ezt a folyamatos kapcsolatot. Ez az új megbízásokat támogathatja. „... hogyha nincs ilyen szerzódés nálunk, akkor a kapcsolat ápolásának van költsége...”, de bizonytalan a hozama.

A kapcsolat értéke viszonylagos, ezért a piacon a kapcsolat- és a tranzakció-orientáció egyaránt jellemzô. A tanácsadói piacon például mindenki kapcsolatorientáltnak véli magát. Ez a bizalmi jellegból adódik. A return on relationship (ROR)-elemzés azonban nem jellemző, a kapcsolatmenedzsment sokkal inkább intuitív.

\section{Összegzés}

Befejezésképpen érdemes a kutatás néhány tanulságát levonni. A csoportvitákból világossá vált, hogy az interaktivitás és az egyediségból következően a személyes kompetenciák fontossága miatt a nagy vállalatméret nagyobb biztonságot jelent emberi erôforrás oldalon. (A helyettesíthetőség fontos, mivel kis beszállítóknál egykét kompetens személy kiválása nagy kockázat!)Ennek ellentmond, hogy a komplex projektek végrehajtásában a kisebb vállalatok sokkal rugalmasabbak. Meglepő gyengesége a legtöbb projektaktornak, hogy a korábbi projektek tanulságait intézményesített formában nem dolgozzák fel, inkább a személyes rutinra és kreativitásra építenek.

Vannak olyan szolgáltatások, mint például a rendezvényszervezés, ahol a referenciák sem tudnak minden problémamegoldó készséget igazolni. Itt a kényszerpályajelleg erôs, jóval túlmutat az ügyletek pénzügyi nagyságrendjén. A projekt (pl. egy vevoótalálkozó) meghiúsulása ugyanis súlyos imázsvesztést okozhat.

Sikerült feltárni, hogy a projektekben mindkét fél kompetenciája értékalakító. A kompetenciaaszimmetria azonban rendkívül üzletágfüggô. Egyes területeken (pl. banki hitelezés) még a szolgáltató tudatos ügyfélorientációját is megkérdőjelezik. Az aktorok általában a másik oldalon vélnek kompetenciahiányt; és a ténylegesnél kisebb aszimmetriát feltételeznek. A kutatásból kiderült, hogy miután az aszimmetria kölcsönös, helyesebb diszkrepanciáról beszélni. Általános vélemény, hogy a szállítók minőségbiztosítási rendszere a kompetencia üzenete. 
A megkérdezettek szerint az információk kölcsönös kommunikációja csökkenti a kockázatérzetet, sốt az interaktivitás kölcsönös megoldási képességet eredményez. A kockázatkommunikáció azonban növelheti a bizonytalanságot, ezért a megoldással együtt kell kommunikálni.

Megállapítható, hogy a projektaktorok emberi eróforrás-menedzsmentjében ritkán történik tudatos kiválasztás. A projektteam vezetése és összetétele inkább intuitív, mint szisztematikus döntés eredménye, ami komoly kockázati tényezô.

Végül említsük meg a témakör nemzetközi dimenzióját is. A multiknál a globális tudás a cégen belül áramlik. Van egy adatbázis, amelyben külföldi tapasztalatokhoz lehet jutni. A bonyolultabb fó- és alvállalkozói viszonyok, továbbá a nyelvi-kommunikációs nehézségek azonban nehezítik a menedzsmentet, az együttmúködést és a kommunikációt. Érdekes vélemény, hogy azokban a fejlett országokban, ahol nagyobb a niche-piac, a kis, specializált projektszállítók is fennmaradnak.

A kutatás megerősítette előzetes feltevésünket, mely szerint a projektjellegú tevékenységek kockázati problematikájában több a közös, mint ami megkülönbözteti óket. Az azonosságok és megkülönböztető jellemzók feltárása további intenzív szakértối kvalitatív kutatást igényel. A projektpiaci kompetenciaalapú marketing leírásához, továbbá az észlelt eredménykockázat determinánsai kapcsolatának meghatározásához pedig egy késóbbi reprezentatív kutatás vezethet el.

\section{Lábjegyzet}

${ }^{1}$ A nagyberendezés terminus a német nyelvú szakirodalomból került át (Großanlagen), és olyan beruházási javak leírására használják, amelyek valamilyen zárt technológiai folyamatot önmagukban képesek megvalósítani (Günter, 1979). A hazai szaknyelv azonos jelentéssel használja még a „komplett létesítmény” vagy „komplett berendezés” terminusokat is.

${ }^{2}$ A projektkompetencia kérdéskörét késôbb részletesen tárgyaljuk. ${ }^{3}$ Egyes projektügyletekben - mint például az ad hoc piackutatás a teljesítés jóságát közvetlenül nem is lehet ellenórizni.

${ }^{4}$ Kompetenciaértékú okirat lehet egy képzési intézmény akkreditációja vagy a szervezet ISO-tanúsítása.

${ }^{5}$ A kutatást 2010-tól az OTKA (K 81565) támogatja.

\section{Felhasznált irodalom}

Anderson, J.C. - Narus, J.A (1990): A Model of Distributor Firm and Manufacturer Firm.Working Partnerships. Journal of Marketing, 54, p. 42-58.

Aqueveque, C. (2006): Extrinsic Cues and Perceived Risk: The Influence of Consumption Situation. Journal of Consumer Marketing 23(5), p. 237-247.

Awuah, G.B. (2001): A firm's competence development through its network of exchange relationships. Journal of Business and Industrial Marketing, 16(7), p. 574-599.
Axelsson B. - Wynstra, F. (2002): Buying Business Services, Wiley, Chichester

Banerjee P. (2003): Resource dependence and core competence: insights from Indian software firms. Technovation, Vol. 23, p. 641-651.

Bettencourt, L.A. - Brown, S.W. - Ostrom, A.L. - Roundtree, R.I. (2002): Client Co-Production in KnowledgeIntensive Business Services. California Management Review, Vol 44, Summer, p. 100-128.

Branscomb, L.M. - Auerswald, Ph.E. (2001): Taking Technical Risks - How Innovators, Executives and Investors manage high-tech risks. The MIT Press, Cambridge MA.

Conceição, P. - Heitor, M.V. (2002): Knowledge interaction towards inclusive learning: Promoting systems of innovation and competence building. Technological Forecasting \& Social Change, Vol. 69, p. 641-651.

Cova B. (1990): Marketing international de projets: un panorama des concepts et des techniques. Revue Française du Marketing, No. 2-3, p. 9-37.

Cova B. - Ghauri, P. - Salle, R. (2002): Project Marketing: Beyond Competitive Bidding. Wiley, New York

Cova B. - Hoskins, S. (1997): A Twin-Track Networking Approach to Project Marketing. European Management Journal, 15(5), p. 546-556.

Cova B. - Salle, R. (1996): The Marketing of Complex Industrial Services: A Pluralist Approach. Proposal for the 4ème Séminaire International de Recherche en Management des Activités de Service, Paris

Cova B. - Salle, R. (1999): Le Marketing d'Affaires. Dunod, Paris

Cova B. - Salle, R. (2007): Introduction to the IMM special issue on 'Project marketing and the marketing of solutions'. A comprehensive approach to project marketing and the marketing of solutions. Industrial Marketing Management, Vol. 36, p. 138-146.

Dhalakia, U.M. (2001): A Motivational Process Model of Product Involvement and Consumer Risk Perception. European Journal of Marketing, 35(11/12), p. 1340-1362.

Dowling, G.R. - Staelin, R. (1994): A Model of Perceived Risk and Intended Risk-Handling Activity. Journal of Consumer Research, 21(June), p. 119-134.

Eng, T. $-Y$. (2005): The Effects of Learning on Relationship Value in a Business Network Context. Journal of Business-to-Business Marketing, 12(4), p. 67-101.

Engelhardt, W. (1993): Vom Produkt zur Dienstleistung!? In: Mein Kunde, seine Situation, unser Geschäft. VDIVerlag, Düsseldorf, p. 85-104.

Ford, D. (ed.) (2002): The Business Marketing Course Managing in Complex Networks. Wiley, Chichester

Ganesan, S. (1994): Determinants of Long-Term Orientation in Buyer-Seller Relationships. Journal of Marketing, 58(April), p. 1-19.

Garai L. (2003): Identitásgazdaságtan. Tas Kiadó, Budapest

Garner, S.J. (1986): Perceived Risk and Information Sources in Services Purchasing. The Mid-Atlantic Journal of Business (Winter), p. 5-15. 
Golfetto, F. - Gibbert, M. (2006): Marketing competencies and the sources of customer value in business markets. Industrial Marketing Management, 35(8), p. 904-912.

Grant, R.M. (1995): Contemporary strategy analysis: Concepts, techniques, applications. Blackwell, Boston MA.

Guseman, D.S. (1981): Risk Perception and Risk Reduction in Consumer Services. In: J.H. Donnelly, and George, W.R (Ed.), Marketing of Services (200-204). American Marketing Association. Chicago

Günter B. (1979): Das Marketing von Großanlagen - Strategieprobleme des Systems Selling. Vertriebs-wirtschaftliche Abhandlungen, Heft 22, Berlin, Duncker \& Humblot

Hadjikhani, A. (1996): Project Marketing and the Management of Discontinuity. International Business Review, 5(3), p. 319-336.

Haimala, J. - Salminen, R.T. (2006): Personal relationships shaping temporary networks - The influence of critical events between persons in project marketing context. Proceedings of the IMP Conference, Milan

Hakansson, H. - Snehota, I. (1995): Developing Relationships in Business Networks. Routledge, London

Hamel G. - Prahalad, C.K. (1994): Competing for the Future, Harvard Business School Press, Boston

Havlena, W.J. - DeSarbo, W.S (1991): On the Measurement of Perceived Risk. Decision Sciences, 22, p. 927-939.

Jacoby J. - Kaplan, L.B. (1972): The Components of Perceived Risk. In: M. Venkatesan (Ed.): Proceedings of the 3rd Annual Conference of the Association for Comumer Research (382-393). Association for Consumer Research. Chicago

Lapierre, J. (2000): Customer-Perceived Value in Industrial Contexts. Journal of Business \& Industrial Marketing, $15(2 / 3)$, p. 122-145.

Lovelock, C. (2001): Services Marketing, Prentice-Hall. Upper Sadle River NJ.

Mandják T. - Pollák G. - Tasi L. - Várday Gy. - Veres Z. (1995): A projekt marketing elôzményei és gyakorlata. Marketing \& Menedzsment, XXIX. évf., No. 3., p. 41-43.

Mandják T. - Simon J. (2007): First steps of the empirically test of the Integrated Business Relationship Value Model. In 23rd International Marketing and Purchasing Group (IMP) Conference, Manchester, p.1-12.

Mandják T. - Veres Z. (1998): The D-U-C Model and the Stages of Project Marketing Process, in: Halinen-Kaila, A. - Nummela, N. (eds.): Visions for the future, IMP Proceedings, Turku, Vol. 1, p. 471-490.

Menon A. - Homburg Ch. - Beutin N. (2005): Understanding Customer Value in Business-to-Business Relationships. Journal of Business-to-Business Marketing, 12(2), p. $1-35$.

Möller K. (2006): Role of competences in creating customer value: A value-creation logic approach. Industrial Marketing Management Volume 35(8), November, p. 913-924.
Murray K.B. - Schlacter J.L. (1990): The Impact of Services versus Goods on Consumers'Assessment of Perceived Risk and Variability. Journal of the Academy of Marketing Science, 18(1), p. 51-65.

Newman R.G. (1988): Single Source Qualification. Journal of Purchasing and Materials Management, 24(2), p. $10-17$.

Page A.L. - Siemplenski M. (1983): Product Systems Marketing. Industrial Marketing Management, No. 2.

Ruofan L. (2009): Managing Perceived Risk and Value in Business-to-Business Contexts: A Conceptual Framework. Dissertation, The University of Auckland, Auckland

Schmidt R.H. - Wagner, G.R. (1985): Risk Distribution and Bonding Mechanisms in Industrial Marketing. Journal of Business Research, No. 5.

Sheth J.N. - Parvatiyar, A. (1995): Relationship Marketing in Consumer Markets: Antecedents and Consequences. Journal of Academy of Marketing Science, 23(Fall), p. 255-271.

Sveiby K.E. (1997): The New Organizational Wealth, Berrett-Koehler, San Francisco CA.

Sweeney J.C., - Soutar, G.N (2001): Consumer Perceived Value: The Development of a Multiple Item Scale. Journal of Retailing, 77(2), p. 203-220.

Taylor J. W. (1974): The Role of Risk in Consumer Behavior. Journal of Marketing, 38(2), p. 54-60.

Theoharakis V. - Sajtos, L. - Hooley, G. (2009): The Strategic Role of Relational Capabilities in the Business-toBusiness Service-Profit Chain. Industrial Marketing and Management, 38(8), p. 914-924.

Vargo S.L. - Lusch, R.F. (2004): Evolving to a New Dominant Logic for Marketing. Journal of Marketing, 68(1), p. $1-17$.

Veres Z. - Buzas, N. (2006): Management des risques bilatéraux dans le transfert de technologie. La Revue du Management Technologique, PUG, Grenoble, 15(2), p. 47-74.

Veres Z. (2007): „A kockázat megmarad, csak az érzet változik" - Tranzakciós és kapcsolati preferenciák a projekttípusú üzleti szolgáltatások piacán. Vezetéstudomány, XXXVIII. évf., 9. sz., p. 51-64.

Veres Z. (2009a): Az SDL - Új stratégiai dimenzió a projektpiacon? in: Bugár Gy. - Farkas F. (szerk.): Elkötelezettség és sokoldalúság - Tanulmánykötet Barakonyi Károly tiszteletére, PTE, KTK, Pécs, p. 239-246.

Veres Z. (2009b): Competence-based risk perception in the project business. Journal of Business and Industrial Marketing, Special Issue, 24(3/4), p. 237-244.

Veres Z. (2009c): A szolgáltatásmarketing alapkönyve. Akadémiai Kiadó, Budapest

Zeithaml V.A. (1988): Consumer Perceptions of Price, Quality, and Value: A Means-End Model and Synthesis of Evidence. Journal of Marketing, 52(3), p. 2-22. 